\title{
The worst thing
}

Cite as: CMAJ 2017 October 30;189:E1342. doi: 10.1503/cmaj.170130

$\mathrm{T}$ he worst thing is the feeling that everyone knows. Knows how I'm feeling, knows what's going on in my head. They're second-guessing me, doubting me, because they can see the shambles inside me. They must know. There's this kid at work, normally full of friendliness, who's been steering clear of me, a wary look on her face. She knows, she must, that kid at work.

But maybe the worst thing is that now I can't work. I shouldn't be working, not in this state. I can't make the simplest decisions. What to wear? What to get at the store? So of course I can't look after patients. But the days spent rattling around the house, just me and the cat, those long days are the worst.

The cat is the worst thing, the way she carries on like everything is normal. People know that I'm a little unhinged on the subject of my cat, that I spoil her, that I rely on her company, that looking after her keeps me sane. But now feeding her is a chore, not a kindness. My hands, tense and numb, seem to communicate no affection when I scratch her chin. She seems not to notice a difference. She curls up on the bed and then purrs and then snores. Her expert example does not help me sleep.

The worst thing, now that I mention it, is not sleeping. Hardly enough room on the pillow for all the malign thoughts that my broken mind is intent on making. That moment when I do manage to fall asleep just long enough to dream of shooting myself in the face, which jolts me awake so that I can spend the rest of the night crying in fear. Maybe crying all night, and all day, maybe that's the worst thing.

The morning, when it finally comes, is the worst. The bed, which terrorized me like a crypt all night, becomes a refuge. Even if I can work up the will to leave it, I move through quicksand, every step. In the kitchen I make a breakfast that I won't eat. My spine warps under the weight of my clothes and I can't get my head up; all I see of the world are its floors. The task of going out there seems impossible.

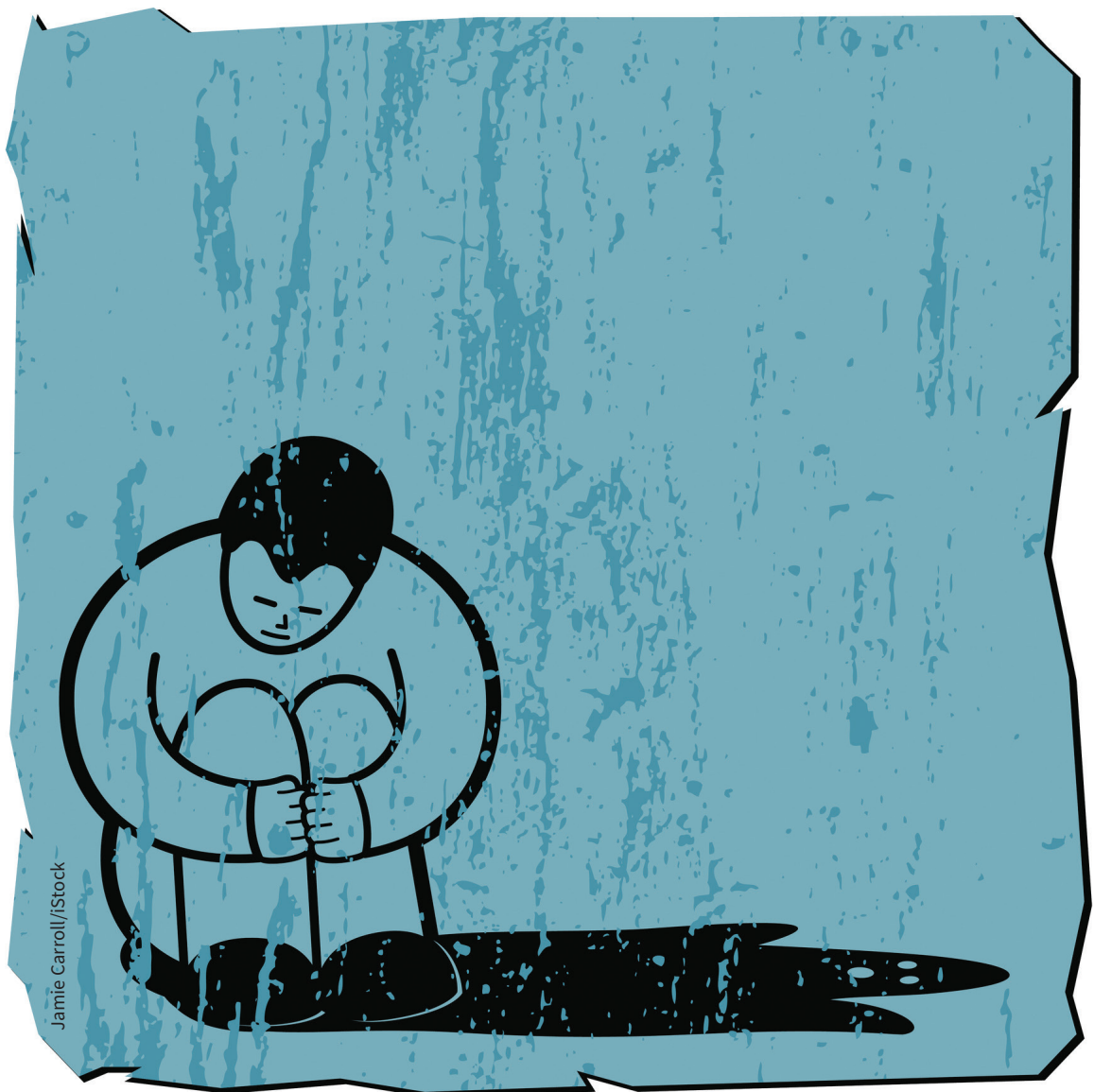

Dealing with the people out there seems beyond impossible, like science fiction.

They're the worst, they are, the other people. My heart is too raw to bear them. My brain is too full of the smog of lies that depression tells me, and so I cannot hear them. To be told that I am loved, when I know that I am flawed and wrecked and unlovable, I am too fragile for that.

I have been this breakable before. That might be the worst thing. Knowing where this is going, knowing how bad it could get. How selfish it's going to make me, consumed by my fractured self. Knowing that l'll use the compassion that people have to give, and then I'll use more than they have to give, and then even more. Knowing that those relationships will never be the same, will be withered by my need.
I know that there will be a moment when feeling nothing will seem preferable to feeling like this. That must be the worst thing. Or perhaps what's worst is the fear that, when that moment comes, I won't have the sense to ask for help.

The person I've become, that must be the worst thing. A weeping troglodyte, whose every act is selfish, whose every thought is an imagined doom. Who does nothing other than hurt. Surely, he is the worst thing.

\section{Paul Moorehead MD}

Janeway Children's Health and

Rehabilitation Centre, St. John's, NL

This article has been peer reviewed.

This is the author's story. 